\title{
САНАЦІЯ ЯК СПОСІБ ЗАПОБІГАННЯ БАНКРУТСТВУ ПІДПРИЕМСТВ
}

\author{
Ольга Кальченко
}

\section{САНАЦИЯ КАК СПОСОБ ПРЕДОТВРАЩЕНИЯ БАНКРОТСТВА ПРЕДПРИЯТИЙ}

\author{
Olha Kalchenko

\section{REORGANIZATION AS A METHOD FOR PREVENTING BANKRUPTCY OF ENTERPRISES}

\begin{abstract}
В умовах нестабільності політичної та економічної ситуачії, щэо негативно вливає на платоспроможність вітчизняних підприємств та створює загрозу їх банкрутства, питання фінансового оздоровлення суб'єктів господарювання нині стають особливо актуальними. У статті розглянуто значення санації підприємств у контексті забезпечення їхньої фінансової стійкості, ліквідності та платоспроможності в кризових умовах; доведено, що санаиія є об'єктивною необхідністю ринкового господарювання, має комплексний характер та охоплює фінансові, виробничі, організаційні та соиіальні аспекти функціонування підприємств. Досліджено теоретичні підходи до визначення санації; обтрунтовано авторське бачення иього терміна, визначена основна мета санації підприємств. Проведено статистичний аналіз стану провадження справ про банкрутство та ефективності його процедури протягом 2011-2019 років.
\end{abstract}

Ключові слова: саначія підприємства; банкрутство; неплатоспроможність; фінансова криза; фінансова стійкість.

Рис.: 1. Табл.: 1. Бібл.: 18.

В условиях нестабильности политической и экономической ситуации, которая негативно влияет на платежеспособность отечественных предприятий и создает угрозу их банкротства, вопросы финансового оздоровления субъектов хозяйствования становятся особенно актуальными. В статье рассмотрено значение санации предприятий в контексте обеспечения их финансовой устойчивости, ликвидности и платежеспособности в кризисных условиях; доказано, что санация является объективной необходимостью рыночного хозяйствования, носит комплексный характер и охватывает финансовые, производственные, организационные и социальные аспекть функиионирования предприятий. Исследованы теоретические подходы к определению санации; обосновано авторское видение данного термина, определена основная иель санации предприятий. Проведен статистический анализ производства дел о банкротстве и эффективности его прочедуры в течение 2011 - 2019 годов.

Ключевые слова: санация предприятия; банкротство; неплатежеспособность; финансовый кризис; финансовая устойчивость.

Рис.: 1. Табл.: 1. Библ.: 18.

Given the instability of the political and economic situation, which negatively affects solvency of domestic enterprises and threatens their bankruptcy, issues of financial recovery of economic entities are now becoming particularly relevant. Within the article, importance of the reorganization of enterprises in the context of ensuring their financial stability, liquidity and solvency in crisis conditions is considered; it is proved that reorganization is an objective necessity of market management; it is complex and covers financial, production, organizational and social aspects of the enterprise operation. Theoretical approaches to the definition of reorganization are studied; the author's vision of this term is substantiated, the main purpose of reorganization of enterprises is defined. A statistical analysis of the state of bankruptcy proceedings and the effectiveness of its procedure during 2011 - 2019 is carried out.

Keywords: reorganization of enterprises; bankruptcy; insolvency; financial crisis; financial stability.

Fig.: 1. Table: 1. References: 18.

JEL Classification: D24

Постановка проблеми. У сучасних умовах нестабільного економічного розвитку України, що зумовлений як економічними, так і політичними чинниками, проблеми банкрутства та санації підприємств стають особливо актуальними. Нині, крім неплатоспроможних підприємств, проти яких порушено справу про банкрутство, є значна кількість вітчизняних підприємств, що тимчасово потрапили в скрутне становище, і одним зі шляхів подолання неплатоспроможності та попередження банкрутства таких суб'єктів господарювання може стати санація.

Аналіз останніх досліджень і публікацій. Питання антикризового управління, управління санацією підприємств та проблеми оцінки ефективності розробленої санаційної концепції досліджували такі закордонні та вітчизняні вчені, як І. Бланк, О. Терещенко, Г. Крамаренко, А. Кунденко [18], І. Тітов, А. Кондрашихін, Л. Лігоненко, О. Поддєрьогін, Г. Федорова, А. Череп та інші. 
ФІНАНСОВІ РЕСУРСИ: ПРОБЛЕМИ ФОРМУВАННЯ ТА ВИКОРИСТАННЯ

Виділення недосліджених частин загальної проблеми. Санації відводиться важлива роль у системі стабілізаційних заходів, що спрямовані на виведення підприємства із фінансової кризи. Як показує практика зарубіжних країн, саме санація підприємств має значний потенціал та належить до найбільш дієвих механізмів фінансового оздоровлення суб'єктів господарювання.

Недосконалість вітчизняного законодавства, дефіцит кваліфікованих кадрів, нестача належного фінансування санаційного процесу, невчасне виявлення проблем та можливості ймовірного банкрутства часто призводять до того, що значна частина фінансово стійких та потенційно платоспроможних підприємств банкрутує [9]. Тому проблеми фінансової неспроможності та банкрутства вітчизняних підприємств, а також питання пошуку шляхів їх фінансового оздоровлення через застосування санаційної процедури потребують поглибленого вивчення.

Метою статті $\epsilon$ розкриття та уточнення сутності та значення санації підприємств у сучасних умовах господарювання в контексті забезпечення їхньої фінансової стійкості, ліквідності та платоспроможності в кризових умовах.

Виклад основного матеріалу. Кризовий стан може виникнути на всіх стадіях життєвого циклу підприємства, тому важливим є своєчасне виявлення сигналів щодо формування внутрішніх або зовнішніх факторів і процесів, які здатні викликати фінансову кризу суб'єкта господарювання. Правильне виявлення ознак фінансової кризи дає змогу вчасно діагностувати фінансову неспроможність підприємства та розробити найефективніші оздоровчі заходи. Тобто для запобігання банкрутству важливо правильно розпізнати причини та ознаки фінансової неспроможності підприємства, а також вміти попередити й ефективно подолати кризові явища на підприємстві.

У цьому напрямку одним із дієвих інструментів, що застосовуються для вчасного виявлення та ефективного запобігання фінансовій кризі на підприємстві, визнано фінансовий моніторинг, у межах якого здійснюється збір та обробка необхідної оперативної інформації, що дозволяє провести оцінювання показників зовнішнього та внутрішнього середовища, а також їхнього впливу на основні фінансові параметри підприємства. У межах фінансового моніторингу проводиться аналіз фінансового стану підприємства, результати якого виступають найважливішою характеристикою його фінансово-економічної діяльності. У процесі аналізу фінансового стану визначаються конкретні напрями, за якими необхідно вести роботу щодо його поліпшення, виявляються найбільш важливі та найбільш слабкі позиції у фінансовому стані цього підприємства для запобігання його банкрутству.

Хоча банкрутство суб'єктів економіки є юридичним фактом, у його основі лежать переважно фінансові причини, до числа яких слід віднести наступне: значне зниження фінансової стійкості підприємства, що перешкоджає нормальному функціонуванню; тривала неплатоспроможність підприємства, що зумовлена нестачею грошових коштів та низькою ліквідністю його активів; суттєва незбалансованість обсягів грошових потоків тощо.

У сучасних нестабільних фінансово-економічних умовах підприємства, що не здатні до конкуренції, не мають власних можливостей подолати фінансову кризу, провести санацію та реструктуризацію можуть стати потенційними банкрутами та припинити своє існування.

Для оцінки ефективності процедур санації або ліквідації боржників в Україні доцільно проаналізувати динаміку провадження справ про банкрутство. Наведені в таблиці дані свідчать про загальну тенденцію зменшення кількості справ про банкрутство, закінчених провадженням протягом 2011-2019 років. Так, у 2019 році кількість таких справ проти 2011 року скоротилась майже в 9 разів. Основною підставою припинення справи про банкрутство вітчизняних підприємств залишається ліквідація, адже саме 
ФІНАНСОВІ РЕСУРСИ: ПРОБЛЕМИ ФОРМУВАННЯ ТА ВИКОРИСТАННЯ

справи, які припинено у зв'язку із затвердженням звіту ліквідатора протягом усіх досліджуваних років, займають найбільшу питому вагу (у 2019 році питома вага таких справ становила 80,5 \%). Дуже низькою у 2019 році, як і протягом попередніх періодів, залишається питома вага справ, що припинені через санацію підприємства-боржника $(0,3 \%)$ та виконання всіх зобов'язань перед кредиторами $(0,2 \%)$, а їх кількість у порівнянні з 2011 р. зменшилась на 50 та 35,8 \% відповідно. Отже, як свідчать статистичні дані, відновлення та оздоровлення суб'єктів господарювання як одне 3 головних завдань інституту банкрутства в українській економіці не реалізується.

Таблиця

Характеристика справ про банкрутство, закінчених провадженням

в Україні протягом 2011-2019 років

\begin{tabular}{|c|c|c|c|c|c|c|c|c|}
\hline \multirow[b]{3}{*}{ Рік } & \multirow[b]{3}{*}{$\begin{array}{c}\text { Кількість } \\
\text { справ, } \\
\text { закінчених } \\
\text { провадженням }\end{array}$} & \multicolumn{6}{|c|}{ Iз них } & \multirow[b]{3}{*}{$\begin{array}{c}\text { Кількість справ, } \\
\text { у яких винесено } \\
\text { постанову } \\
\text { про визнання } \\
\text { банкрутом }\end{array}$} \\
\hline & & \multirow[b]{2}{*}{$\begin{array}{c}\text { залишено без } \\
\text { розгляду }\end{array}$} & \multicolumn{5}{|c|}{ припинено у зв'язку } & \\
\hline & & & 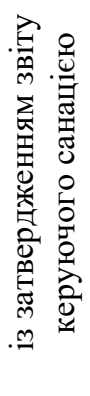 & 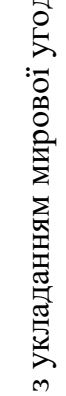 & 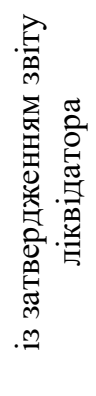 & 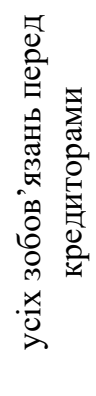 & 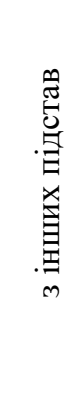 & \\
\hline 2011 & 10382 & 523 & 8 & 106 & 8335 & 100 & 1310 & 6745 \\
\hline 2012 & 7583 & 275 & 8 & 94 & 6084 & 101 & 1021 & 4631 \\
\hline 2013 & 5697 & 128 & 7 & 82 & 4948 & 57 & 475 & 3359 \\
\hline 2014 & 3324 & 55 & 4 & 70 & 2989 & 29 & 177 & 2096 \\
\hline 2015 & 2406 & 32 & 8 & 53 & 2159 & 6 & 148 & 1799 \\
\hline 2016 & 2101 & 29 & 1 & 48 & 1844 & 18 & 16 & 1385 \\
\hline 2017 & 1691 & 12 & 1 & 32 & 1546 & 11 & 86 & 1242 \\
\hline 2019 & 1184 & 14 & 4 & 68 & 953 & 2 & 137 & 649 \\
\hline
\end{tabular}

Джерело: [14].

На думку експертів, вітчизняна процедура банкрутства дуже неефективна, дорога та занадто тривала порівняно з розвиненими країнами, у яких, на відміну від України, майже 60-85 \% справ про банкрутство закінчується відновленням платоспроможності підприємств. Показник відшкодування вимог кредиторів в Україні в середньому становить $9 \%$, тоді як у країнах Східної Свропи і Середньої Азії - 28 \%. На процедури, пов'язані з банкрутством, в Україні витрачається $42 \%$ коштів від загальної вартості бізнесу, а країнах Східної Свропи й Середньої Азії - усього 13 \% [17].

У 2019 році за даними дослідження проєкту Світового банку «Doing Business» за напрямом «Врегулювання неплатоспроможності» Україна посідає 145-е місце в рейтингу, зміцнивши свою позицію на 4 сходинки порівняно із 2018 роком [10; 13]. Головними причинами низького рейтингу України є:

1) занадто тривала процедура в Україні - 2,9 року (Східна Європа та Центральна Азія - 2,3 року; розвинуті країни - 1,7 року). Краща країна - 0,4 року (Ірландія);

2) висока вартість процедур банкрутства в Україні - 40,5 \% від вартості майна боржника (Східна Свропа та Центральна Азія - 13,1 \%; розвинуті країни - 9,1 \%). Краща країна - Норвегія $(1,0 \%)$; 
ФІНАНСОВІ РЕСУРСИ: ПРОБЛЕМИ ФОРМУВАННЯ ТА ВИКОРИСТАННЯ

3) низька ефективність процедур банкрутства в Україні (індекс стягнення/центи на долар) - 8,9 (Східна Європа та Центральна Азія - 38; розвинуті країни - 71,2). Краща країна - Норвегія $(93,1)$ [7].

Сьогодні в Україні продовжується реформування інституту банкрутства. 321 жовтня 2019 року введений у дію Кодекс України з процедур банкрутства, який є основним нормативним документом, що регулює питання, пов'язані з банкрутством і санацією суб'єктів господарювання в Україні. Він встановлює умови та порядок санації, порядок визнання суб'єкта господарювання банкрутом та застосування ліквідаційної процедури 3 метою найповнішого задоволення вимог кредиторів.

Прийнятий законодавчий акт має певні новації в порівнянні з попередньо чинним Законом України «Про відновлення платоспроможності боржника або визнання його банкрутом». Так, однією з новацій цього Кодексу стало запровадження та врегулювання процедури банкрутства фізичних осіб. Також змінились умови відкриття провадження справи про банкрутство. На відміну від Закону України «Про відновлення платоспроможності боржника або визнання його банкрутом», згідно з яким «справа про банкрутство порушується господарським судом, якщо безспірні вимоги кредитора (кредиторів) до боржника сукупно становлять не менше трьохсот мінімальних розмірів заробітної плати, які не були задоволені боржником протягом трьох місяців після встановленого для їх погашення строку, якщо інше не передбачено цим законом» [12], відповідно до статті 8 Кодексу підставою для відкриття провадження у справі про банкрутство за заявою боржника є загроза його неплатоспроможності.

Поняття загрози неплатоспроможності наведено в частині шостій статті 34 Кодексу. Вона пов'язана 3 наявністю обставин, за яких задоволення вимог одного або кількох кредиторів призведе до неможливості виконання грошових зобов'язань боржника в повному обсязі перед іншими кредиторами [2].

Неспроможність боржника виконати після настання встановленого строку грошові зобов'язання перед кредиторами не інакше, як через застосування процедур, передбачених Кодексом, свідчить про неплатоспроможність боржника. Отже, підставою для застосування до боржника встановлених Кодексом процедур та, відповідно, відкриття провадження у справі є неплатоспроможність боржника. Ознакою такої неплатоспроможності є наявність невиконаного боржником зобов'язання перед кредитором незалежно від його розміру та строку невиконання [2].

Але деякі науковці вважають це певним недоліком. Так, на думку Б. Полякова, «легкість відкриття справ про банкрутство робить Кодекс чудовим “інструментом” для рейдерських захоплень підприємств, зміни підсудності справ позовного провадження, визнання законних угод недійсними, неповернення боргів і кредитів, несплати податків» [11].

Загальновідомо, що в умовах ринкової економіки банкрутство $є$ саме тим механізмом, за допомогою якого відбувається відбір сильних та успішних суб'єктів господарювання. Але неправильно вважати, що з кризою стикаються тільки слабкі підприємства 3 неефективним менеджментом. Хоч статистичні дані (рис. 1) і свідчать про зниження питомої ваги збиткових підприємств в Україні протягом 2010-2018 років, будь-яке підприємство під час своєї діяльності може отримати від'ємний фінансовий результат та опинитись у кризовому стані. Своєчасне реагування на симптоми розвитку кризи та впровадження заходів щодо її нейтралізації надає підприємствам реальну можливість відновити свою платоспроможність та фінансову стійкість. 
ФІНАНСОВІ РЕСУРСИ: ПРОБЛЕМИ ФОРМУВАННЯ ТА ВИКОРИСТАННЯ

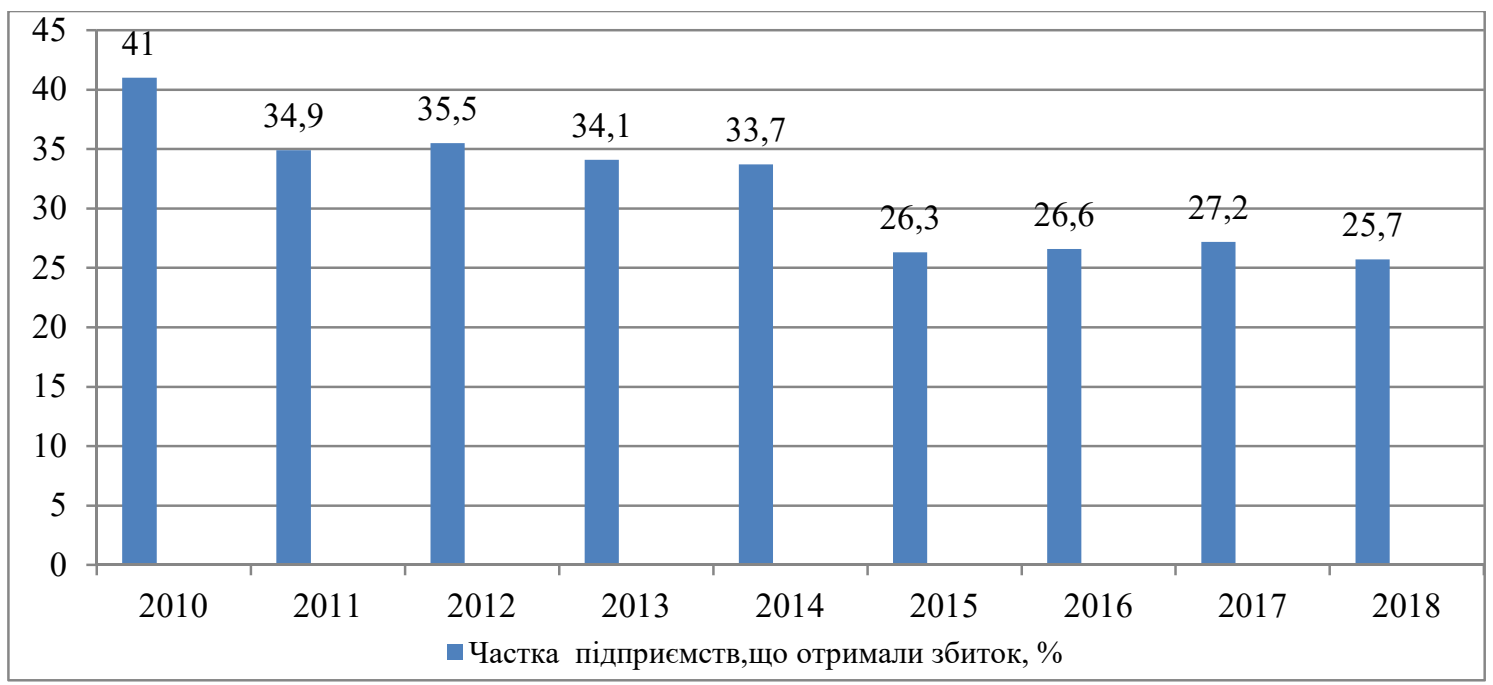

Рис. 1. Частка підприємств, щзо отримали від'ємний фінансовий результат до оподаткування, \%

Джерело: [3].

Майбутнє кожного суб'єкта господарювання великою мірою залежить від того, чи зможе воно подолати тимчасові кризові явища та відновити ефективну діяльність. Одним зі шляхів запобігання кризових явищ та покращення фінансового стану є розробка та впровадження санаційних заходів.

У спеціальній літературі $є$ різні підходи до визначення економічної сутності терміна «санація». Він походить від латинського «sanare» і перекладається як оздоровлення. I. А. Бланк визначає, що санація - це заходи щодо фінансового оздоровлення підприємства, які реалізуються з допомогою сторонніх юридичних чи фізичних осіб і спрямовані на запобігання оголошенню підприємства-боржника банкрутом і його ліквідації [1].

I. I. Тітов характеризує санацію як «сукупність заходів для усунення збитків, фінансової стабілізації підприємства та покращення його фінансового стану за рахунок зовнішніх та внутрішніх джерел фінансування» [16].

У [4] це поняття трактується як «процедура, що передбачає заходи щодо фінансового оздоровлення боржника, тобто відновлення платоспроможності». Г. О. Крамаренко і О. Є. Чорна зауважують, що поняття «санація» означає «систему заходів, проведених для поліпшення фінансового стану підприємства з метою запобігання їх банкрутства та підвищення конкурентоспроможності, особливо в періоди економічних криз» [8].

У [5] під санацією розуміється оздоровлення неспроможного боржника, надання йому фінансової допомоги з боку власника майна, кредиторів та інших юридичних та фізичних осіб, спрямовані на підтримку діяльності боржника і запобігання його банкрутства.

Найбільш змістовне визначення санації дається в працях О. О. Терещенко: «систему фінансово-економічних, виробничо-технічних, організаційно-правових, соціальних заходів, спрямованих на відновлення платоспроможності, ліквідності та прибутковості підприємства-боржника» [15].

У вітчизняному законодавстві про банкрутство розглядається два види санації:

- санація боржника до відкриття провадження у справі про банкрутство - це система заходів щодо відновлення платоспроможності боржника, які може здійснювати засновник (учасник, акціонер) боржника, власник майна (орган, уповноважений управляти майном) боржника, інші особи з метою запобігання банкрутству боржника шляхом вжиття організаційно-господарських, управлінських, інвестиційних, технічних, фінансово-економічних, правових заходів відповідно до законодавства до відкриття провадження у справі про банкрутство [6]; 
ФІНАНСОВІ РЕСУРСИ: ПРОБЛЕМИ ФОРМУВАННЯ ТА ВИКОРИСТАННЯ

- санація як «система заходів, що здійснюються під час провадження у справі про банкрутство з метою запобігання визнанню боржника банкрутом та його ліквідації, спрямованих на оздоровлення фінансово-господарського становища боржника, а також задоволення в повному обсязі або частково вимог кредиторів шляхом реструктуризації підприємства, боргів і активів та/або зміни організаційно-правової та виробничої структури боржника» [6].

Вони розрізняються часом проведення та кінцевою метою. Так, головною метою санації боржника до відкриття провадження у справі про банкрутство є запобігання банкрутству підприємств, у той час як при здійсненні санації в процесі провадження справи про банкрутство ще однією метою проведення санаційних заходів зазначається задоволення вимог кредиторів.

Таким чином, у наукових джерелах до тлумачення терміна «санація» використовується два підходи: широкий, за яким під санацією розуміють сукупність усіх заходів, що здійснюються з метою ліквідації проблем у діяльності підприємства та забезпечення його ефективного функціонування $[8 ; 15 ; 16]$, та вузький, при якому термін «санація» використовується для характеристики заходів з недопущення ліквідації та банкрутства підприємств [5; 6]. Також можна виділити переважно два головні завдання санації які сформульовані при іiї визначенні - попередження банкрутства, а також відновлення платоспроможності, ліквідності та прибутковості суб'єкта господарювання.

Отже, санація - це комплекс фінансово-економічних, виробничо-технічних, організаційно-правових, соціальних заходів, метою яких є відновлення платоспроможності підприємства-боржника, оздоровлення його фінансового стану, задоволення повністю або частково вимог кредиторів і недопущення банкрутства.

Процедура санації, з одного боку, виступає елементом правового регулювання механізму банкрутства, а з іншого - економічним інструментом відновлення фінансової стійкості, ліквідності та платоспроможності, який включає в себе фінансову, виробничу, соціальну та організаційну складові.

Метою санації є фінансове оздоровлення підприємства (покриття поточних збитків, зменшення заборгованості, підвищення платоспроможності та ліквідності), запобігання негативних тенденцій у фінансово-господарській діяльності, підвищення основних техніко-економічних показників, створення умов для активного виробничого, фінансового та соціального розвитку суб'єкта господарювання.

На вітчизняних підприємствах санація може проводитись у трьох випадках:

- до порушення справи про банкрутство, коли керівництво підприємства за власною ініціативою приймає рішення про фінансове оздоровлення та вихід із кризової ситуації за допомогою внутрішніх і зовнішніх джерел та резервів;

- коли боржник за рішенням засновників ініціює процедуру санації до відкриття провадження у справі про банкрутство і звертається до господарського суду із планом санації;

- коли рішення про санацію ухвалює господарський суд у ході провадження справи про банкрутство підприємства-боржника.

У двох останніх випадках санація здійснюється через господарський суд, який призначає керуючого санацією та ухвалює план санації за умови згоди комітету кредиторів та всіх інших кредиторів, які відповідно до плану санації беруть у ній участь.

Перший випадок проведення санації, яка ініціюється самим підприємством і не передбачає звернення до господарського суду, має попереджувальний характер, більш широкий спектр дій та підпорядкована завданням антикризового управління підприємством.

Відповідно до Кодексу України з процедур банкрутства заходами щодо відновлення платоспроможності боржника, які містить план санації, можуть бути:

- реструктуризація підприємства;

- перепрофілювання виробництва; 
ФІНАНСОВІ РЕСУРСИ: ПРОБЛЕМИ ФОРМУВАННЯ ТА ВИКОРИСТАННЯ

- закриття нерентабельних виробництв;

- відстрочення, розстрочення або прощення боргу чи його частини;

- виконання зобов'язання боржника третіми особами;

- задоволення вимог кредиторів в інший спосіб, що не суперечить цьому Кодексу;

- ліквідація дебіторської заборгованості;

- реструктуризація активів боржника відповідно до вимог цього Кодексу;

- продаж частини майна боржника;

- виконання зобов'язань боржника власником боржника та його відповідальність за невиконання взятих на себе зобов'язань;

- відчуження майна та погашення вимог кредиторів шляхом заміщення активів;

- звільнення працівників боржника, які не можуть бути задіяні в процесі виконання плану санації;

- одержання кредиту для виплати вихідної допомоги працівникам боржника, які звільняються згідно з планом санації, що відшкодовується відповідно до вимог цього Кодексу позачергово за рахунок продажу майна боржника;

- одержання позик та кредитів, придбання товарів у кредит;

- інші заходи з відновлення платоспроможності боржника [6].

При визначенні переваг застосування санації для відновлення платоспроможності сучасних підприємств можна зазначити наступне: санація є простішою процедурою, ніж ліквідація; суб'єкт господарювання має можливість відновити свою роботу; більш короткий термін iі проведення в порівнянні з ліквідацією, а у разі неможливості відновлення фінансової стійкості та платоспроможності залишається ще один вихід - ліквідація.

Висновки і пропозиції. Отже, санація підприємства спрямована на його збереження шляхом розробки та впровадження комплексної програми оздоровлення та розвитку і включає в себе систему стабілізуючих заходів, спрямованих на виявлення та використання прихованих резервів та додаткових стимулів для ефективної фінансовогосподарської діяльності підприємства. Вона може здійснюватись по багатьох напрямах, охоплюючи всі сторони та напрями господарської діяльності.

У процесі ефективного впровадження і реалізації санаційних заходів управлінський апарат підприємств повинен спрямовувати свої дії на забезпечення фінансової стійкості, підвищення платоспроможності та ліквідності, збільшення рентабельності суб'єкта господарювання. У таких умовах підприємство має швидко реагувати на всі зміни ринкового середовища, а для цього на ньому повинні бути організовані служби, які б здійснювали постійний аналіз зовнішньої та внутрішньої ситуації. 3 цією метою повинен бути розроблений ефективний механізм взаємодії структурних підрозділів підприємства шляхом вертикальної і горизонтальної інтеграції всіх служб, чіткого визначення функцій кожної, правильного й доцільного делегування повноважень і ступеня відповідальності.

Незважаючи на те, що впровадження санації приводить до покращення становища, в Україні вона не користується великою популярністю. Факторами, що здебільшого стримують процеси фінансової санації на вітчизняних підприємствах, як показує практика, $є$ недосконале правове регулювання, недостатня поінформованість та забезпеченість проведення процесу санації, нестача грошових ресурсів фінансування санації, дефіцит кваліфікованого персоналу. В Україні серед законодавчої процедури банкрутства переважає механізм, орієнтований на ліквідацію, а не на відновлення платоспроможності господарюючих суб'єктів [9].

\section{Список використаних джерел}

1. Бланк И. А. Финансовый менеджмент : учебный курс. Киев : Эльга, Ника-Центр, 2004. 656 с.

2. Вечірко І. Умови відкриття провадження у справі про банкрутство згідно з нормами Кодексу України з процедур банкрутства. Застосування норм Кодексу Украӥни з процедур банкрутства \% збірка наукових статей / за заг. ред. д.ю.н., судді Верховного Суду С. В. Жукова. Київ : Алерта, 2019. 216 с. 
ФІНАНСОВІ РЕСУРСИ: ПРОБЛЕМИ ФОРМУВАННЯ ТА ВИКОРИСТАННЯ

3. Державна служба статистики України. URL: http://www.ukrstat.gov.ua.

4. Єльсуков В. П., Каменков В. С., Конанов Б. И., Ельсуков В. П. Антикризисное управление предприятием. Минск : Аверсэв, 2003. 574 с.

5. Кизим М. О., Забродський В. А. Оцінка і діагностика фінансової стійкості підприємства : монографія. Харків : ВД «ІНЖЕК», 2003. 144 с.

6. Кодекс України з процедур банкрутства від 18 жовтня 2018 року № 2597-VIII. URL: https://zakon.rada.gov.ua/laws/show/2597-19.

7. Константиновський С. Кодекс України з процедур банкрутства: новели та перспективи. Підприємництво, господарство і право. 2019. № 5. С. 88-92.

8. Крамаренко Г. О. Фінансовий менеджмент : підручник. Київ : Центр навчальної літератури, 2006. $520 \mathrm{c.}$

9. Пігуль Н. Г., Семенець В. П. Сутність та значення санації підприємства в сучасних умовах господарювання. Економіка і суспільство. 2019. № 20. С. 359-365.

10. Підгородецька А. Реформування системи неплатоспроможності: антикорупційна спрямованість Кодексу України з процедур банкрутства. Застосування норм Кодексу України з процедур банкрутства : збірка наукових статей / за заг. ред. д.ю.н., судді Верховного Суду С. В. Жукова. Київ : Алерта, 2019. 216 с.

11. Поляков Б. Принцип доміно, або як КзПБ може спровокувати ланцюгове падіння підприємств країни. Закон і Бізнес. 2019. 3-9 серпня (№ 30 (1432)). С. 13-15.

12. Про відновлення платоспроможності боржника або визнання його банкрутом : Закон України від 14.05.1992 № 2343-XII. URL: https://zakon.rada.gov.ua/laws/show/2343-12.

13. Рейтинг «Doing Business 2018»/ Світовий банк. URL: http://russian.doingbusiness.org/ ru/rankings.

14. Судова влада України. URL: https://court.gov.ua/inshe/sudova_statystyka.

15. Терещенко О. О. Фінансова санація та банкрутство підприємств : навч. посіб. Київ : KHEУ, 2004. 412 c.

16. Тітов І. І. Банкрутство: матеріально-правові та процесуальні аспекти. Харків : Консул, 1997. $192 \mathrm{c}$.

17. Хаджинова О. В. Сучасні тенденції банкрутства підприємств в Україні. Теоретичні $i$ практичні аспекти економіки та інтелектуальної власності. 2013. Вип. 1. Т. 2. С. 275-278.

18. Kundenko A., Dorosh M., Baraniuk I., Itchenko D. Crisis management of small and medium businesses in regional economic policy system. Economic Annals-XXI. 2015. № 5-6. P. 108-111.

\section{References}

1. Blank, I. A. (2004). Finansovyi menedzhment [Financial management]. Kiev: Elga, NikaTsentr [in Russsian].

2. Vechirko, I. (2019). Umovy vidkryttia provadzhennia u spravi pro bankrutstvo zghidno z normamy Kodeksu Ukrainy z protsedur bankrutstva [Conditions for opening bankruptcy proceedings in accordance with the provisions of the Code of Ukraine on the Bankruptcy Proceedings]. In S. V. Zhukov (Ed.), Zastosuvannia norm Kodeksu Ukrainy z protsedur bankrutstva-Application of the norms of the Code of Ukraine on the Bankruptcy Proceedings. Kyiv: Alerta [in Ukrainian].

3. Derzhavna sluzhba statystyky Ukrainy [State Statistics Service of Ukraine]. Retrieved from http://www.ukrstat.gov.ua.

4. Ielsukov, V. P., Kamenkov, V. S., Konanov, B. I., Elsukov, V. P. (2003). Antikrizisnoe upravlenie predpriiatiem [Anti-crisis management of the enterprise]. Minsk: Aversev [in Russsian].

5. Pro vidnovlennia platospromozhnosti borzhnyka abo vyznannia yoho bankrutom [On Restoring a Debtor's Solvency or Recognizing It Bankrupt]. № 2343-XII (on May 14, 1992). Retrieved from https://zakon.rada.gov.ua/laws/show/2343-12.

6. Kyzym, M. O., Zabrodskyi, V. A. (2003). Otsinka i diahnostyka finansovoi stiikosti pidpryiemstva [Assessment and diagnosis of financial stability of the enterprise]. Kharkiv: $\mathrm{VD}$ «INZhEK» [in Ukrainian].

7. Kodeks Ukrainy $\mathrm{z}$ protsedur bankrutstva [Code of Ukraine on Bankruptcy Procedures]. № 2597-VIII (on October 18, 2018). Retrieved from https://zakon.rada.gov.ua/laws/show/2597-19. 
ФІНАНСОВІ РЕСУРСИ: ПРОБЛЕМИ ФОРМУВАННЯ ТА ВИКОРИСТАННЯ

8. Konstantynovskyi, S. (2019). Kodeks Ukrainy z protsedur bankrutstva: novely ta perspektyvy [The Code of Ukraine on Bankruptcy Procedures: short stories and prospects]. Pidpryiemnytstvo, hospodarstvo i pravo - Entrepreneurship, economy and law, 5, 88-92 [in Ukrainian].

9. Kramarenko, H. O. (2006). Finansovyi menedzhment [Financial management]. Kyiv: Tsentr navchalnoi literatury [in Ukrainian].

10. Pihul, N. H., Semenets, V. P. (2019). Sutnist ta znachennia sanatsii pidpryiemstva v suchasnykh umovakh hospodariuvannia [The essence and significance of the reorganization of the enterprise in modern business conditions]. Ekonomika i suspilstvo - Economy and society, 20, 359365 [in Ukrainian].

11. Pidhorodetska, A. (2019). Reformuvannia systemy neplatospromozhnosti: antykoruptsiina spriamovanist Kodeksu Ukrainy z protsedur bankrutstva [Reforming the insolvency system: anticorruption orientation of The Code of Ukraine on Bankruptcy Procedures]. In S. V. Zhukov (Ed.), Zastosuvannia norm Kodeksu Ukrainy z protsedur bankrutstva - Application of the norms of The Code of Ukraine on Bankruptcy Procedures. Kyiv: Alerta [in Ukrainian].

12. Poliakov, B. (2019, August 3-9). Pryntsyp domino, abo yak KzPB mozhe sprovokuvaty lantsiuhove padinnia pidpryiemstv krainy [Principle of dominoes, or how the SUP can provoke a chain decline of enterprises in the country]. Zakon i Biznes - Law and Business, 30 (1432), 13-15 [in Ukrainian].

13. Svitovyi bank [World Bank] (n.d.). Reitynh «Doing Business 2018» [Rating "Doing Business 2018']. Retrieved from http://russian.doingbusiness.org/ru/rankings.

14. Sudova vlada Ukrainy [Judicial power of Ukraine]. Retrieved from https://court.gov.ua/inshe/ sudova_statystyka.

15. Tereshchenko, O. O. (2004). Finansova sanatsiia ta bankrutstvo pidpryiemstv [Financial reorganization and bankruptcy of enterprises]. Kyiv: KNEU [in Ukrainian].

16. Titov, I. I. (1997). Bankrutstvo: materialno-pravovi ta protsesualni aspekty [Bankruptcy: substantive and procedural aspects]. Kharkiv: Konsul [in Ukrainian].

17. Khadzhynova, O. V. (2013). Suchasni tendentsii bankrutstva pidpryiemstv v Ukraini [Modern trends in the bankruptcy of enterprises in Ukraine]. Teoretychni i praktychni aspekty ekonomiky ta intelektualnoi vlasnosti - Theoretical and practical aspects of economics and intellectual property, 1 (2), 275-278 [in Ukrainian].

18. Kundenko, A., Dorosh, M., Baraniuk, I., Itchenko, D. (2015). Crisis management of small and medium businesses in regional economic policy system.Economic Annals-XXI, 5-6, 108-111.

Кальченко Ольга Миколаївна - кандидат економічних наук, доцент, доцент кафедри фінансів, банківської справи та страхування, Чернігівський національний технологічний університет (вул. Шевченка, 95, м. Чернігів, 14035, Україна).

Кальченко Ольга Николаевна - кандидат экономических наук, доцент, доцент кафедры финансов, банковского дела и страхования, Черниговский национальный технологический университет (ул. Шевченко, 95, г. Чернигов, 14035, Украина).

Kalchenko Olha - PhD in Economics, Associate Professor, Associate Professor of Department of Finance, Banking and Insurance, Chernihiv National University of Technology (95 Shevchenka Str., 14035 Chernihiv, Ukraine).

E-mail: onkalchenko.2014@gmail.com

ORCID: https://orcid.org/0000-0002-7120-9843

Researcher ID: H-2185-2014 